\title{
Oor die betekenis van die maagdelike geboortetradisie: 'n Debat in die Nederduitsch Hervormde Kerk
}

\author{
P B Boshoff (Vereeniging) \\ Navorsingsassosiaat: Hervormde Teologiese Kollege \\ Universiteit van Pretoria
}

\begin{abstract}
The meaning of the tradition of the virgin birth:

A discussion in the Nederduitsch Hervormde Kerk

This essay explains the meaning attached to the tradition of the virgin birth according to conservative, liberal and balanced readings. Topics that feature in the course of the argument are fundamentalism, liberalism, kerygma and the experience and verbalisation of the kerygma. Fundamentalism is defined as the inability to discern between gospel and theology. Liberalism is the willingness to renounce the concept of revelation. The gospel is proclaimed by performative language. Dogma is the explanation of belief which precedes it. In conclusion an explanation of the meaning of the tradition of the virgin birth based on proposed hermeneutical principles, is given.
\end{abstract}

\section{INLEIDING}

Wat ek met hierdie artikel beoog is die aandui van 'n teologiese denkweg wat in die huidige debat in die Nederduitsch Hervormde Kerk grootliks uit die oog verloor word omdat die toneel oorheers word deur ander gevoelens. Om langs die ingeslane weg te beweeg is dit nodig om sowel na regs as na links af te trap. Ek besef terdeë dat links en regs nie duidelike omskrywings is nie, maar gebruik hulle nogtans omdat dit kan help om aan te dui dat daar 'n derde moontlikheid is, naamlik om nie aan een van die twee partye te behoort nie. Noem dit ' $n$ middeweg, as u wil. Die middeweg wil ook die beste deel van die twee uiterstes verenig: die kritiese ingesteldheid van links, sowel as die ingesteldheid op die Goddelike waarheid van regs. Die waarheid van God en mens is mans genoeg vir al die kritiek en verwelkom dit. Van links word die historiese kritiek heelhartig aanvaar en van regs dat die Bybel getuig van die 
openbaring van God in Jesus Christus. Hoe vrugbaar hierdie moeite gaan wees, sal net die tyd leer.

\section{FUNDAMENTALISME}

Die geykte vraag waarmee die fundamentalistiese beweging in die Christendom moontlike vyande uitsnuffel is die vraag na die maagdelike geboorte: Sê bietjie wat jou houding oor die maagdelike geboorte is sodat ons kan besluit waar jy staan, of jy vriend of vyand is. Wanneer iemand hierdie "Sjibbolet" reg uitspreek word hy goedgekeur op grond van sy gepaste konserwatisme, sou hy egter "Sibbolet" uitkry, word hy summier afgeskryf of uitgewerp as ongelowig, vrysinnig en krities. Nie dat die tema van die maagdelike geboorte 'n groot rol in die denke van fundamentaliste self speel nie (vgl Barr 1981:176). Dit is eintlik meer hulle toetsvraag aan ander mense. Sou iemand antwoord dat hy in die maagdelike geboorte glo as in ooreenstemming met historiese feite, betuig hy daarmee sy bereidwilligheid om die Bybelse beriggewing as feitelike waarhede te lees en te aanvaar. So iemand word deur die fundamentliste aanvaar omdat hy inval by hulle manier van Skrifhantering. Hulle is van mening dat die Bybel volgens die styl van feitelike beriggewing geskryf is en dat dit nie anders as so na regte gelees en aanvaar moet word nie. Van iemand wat die maagdelike geboorte as fisiese, biologiese gebeurtenis aanvaar, word verwag dat hy hom by ander soortgelyke vraagstukke ook by die konserwatiewe fundamentalistiese standpunt sal voeg. Werklike, materiële gebeurtenisse is die soort waarheid wat vir hulle belangrik is. Dat die maagdelike geboortetradisie ooreenstem met historiese feite is vir hulle die voor die hand liggende siening van die saak. Die objektiwiteit van God en sy woord mag nie in gedrang gebring word nie, want dit is ook sy werklikheid.

Hoewel die fundamentalistiese geestesrigting sterk in die omgewing van en ook binne die Nederduitsch Hervormde Kerk figureer en selfs 'n dreigende houding inneem teenoor almal wat die uitgangspunt nie deel nie, is dit nie genoeg rede om die gevoelens nie maar nogtans te weerstaan nie. 'n Bietjie weerstand teen die kwalik bedekte dreigement wat so ewe op die agter buiteblad van Professor H G Van der Westhuizen (2000) se "nuwe Ongeloof" pryk, dat hy die auctor primarius van die dwaalleerklag teen prof A S Geyser was, kan niemand kwaad doen nie en ander dalk help om onder die druk van die fundamentalisme uit te kom. En daar is baie wat nie self fundamentaliste wil wees nie, maar op wie die fundamentalistiese argumente en houding 'n diep indruk maak.

Wat vir die fundamentalisme belangrik is, is objektiwiteit. Maar wat hou hierdie standpunt in? Wat impliseer objektiwiteit? Dit is 'n benadering tot 
kennisverwerwing waarin die natuurlike mens 'n bepaalde voorwerp van buite benader om teoretiese of praktiese kennis daarvan op te doen. Die houding wat die ondersoeker inneem, is dat hy oor die voorwerp van sy ondersoek beskik, hy oefen sy reg daarop uit. Waar die maagdelike geboorte as feitelike gegewenheid aanvaar word, dien dit tegelykertyd as die objektivering van die goddelikheid van Jesus. Hierdie benadering gaan van die veronderstelling af uit dat ek God kan ontmoet sonder om deur God bevraagteken te word, sonder die "vanwaar Gehasi?", en sonder om aan God die eer te gee wat God toekom; die mens stel in sy soewereiniteit die goddelike as verskynsel vas sonder om self daardeur geraak te word. Die objektiverende wêreldbeskouing word deur die mens gebruik om hom te beskerm teen 'n moontlike ontmoeting met die Goddelike werklikheid.

Al sou dit die bedoeling - natuurlik 'n goeie bedoeling - van die konserwatiewe eksegese wees om die transendente van die Nuwe Testament met so 'n benadering te behou, kan Bybelse teoloë nie met die uitvoering daarvan saamgaan nie. Die Bybel bevat 'n waarheid wat langs 'n ander weg ontsluit kan en moet en wil word. Die Bybelse bedoeling is nie om kennis mee te deel in die vorm van algemene stellings wat waar is afgesien van die leser se houding daarteenoor nie. Waarmee ons vanselfsprekend nie sê dat die Nuwe-Testamentiese skrywers sou getwyfel het aan die werklikheid van wat hulle geskryf het nie. Maar 'n werklikheid wat nie bloot as gegewe beskou kan word nie, asof ons onsself daarmee kan bemagtig om oor die goddelike in die wonder te beskik nie. Hulle het hulleself nie in die modernistiese posisie ingeskuif om die werklikheid waarvan hulle getuig in die sin van suiwer feitlikheid te sien nie. Van heilsfeite, as objektief vasstelbare feite, wat die heil veroorsaak en waaruit dit ontvang kan word of ook nie ontvang kan word nie, het hulle nie geweet nie. Vir hulle sou 'n geloof in heilsfeite 'n geloof kleiner as 'n mosterdsaadjie wees. Die Nuwe-Testamentiese skrywers het nie oor heil vertel of bloot daarna verwys nie, maar het die heil verkondig.

\section{VERKONDIGING}

Vir die verkondiging het die fundamentalistiese standpunt verreikende gevolge. Daarvolgens kom die geloof nie meer uit die hoor van die woord nie, maar uit die heilsfeite wat die moontlikheid en werklikheid daarvan waarborg. Die heilsfeite maak die hoofbeginsel uit waarby die verkondiging as aanvulling kom. Van der Westhuizen (2000:55) meen om volgens hierdie skema die Goddelike wonder van die opstanding onder beskerming te neem teen die menslike wonder van die verkondiging. Volgens die Nuwe Testament egter moet die verkondiging nie as 'n tweede fase van die heilshandeling verstaan word nie. "Die geloof kom dus deur die prediking wat 'n mens hoor, en die 


\section{Oor die betekenis van die maagdelike geboortetradisie}

prediking wat ons hoor, is die verkondiging van Christus" (Rom 10:17). Dit is gevolglik nie heil in die eerste plek en dan in die tweede plek 'n mededeling daaroor nie. Die verkondiging is nie minder oorspronklik as die heil nie. Die heilsverkondiging is ook heilsdaad. Dit is duidelik dat so 'n woord wat ook daad is, nie deur historiese feite geverifieer kan word nie en ook nie nodig het om daardeur geverifieer te word nie. Die sogenaamde feite van geboorte, kruis, opstanding en verhoging van Jesus kry betekenis omdat dit in die verkondiging gebruik word om God se heilsdaad aan die wêreld te verduidelik.

Verkondiging verskaf nie inligting oor 'n bepaalde gebeurtenis tot heil van die mens nie; verkondiging bring die heil tot stand, dit doen wat dit sê: "Jou sondes is jou vergewe." Die mens wat hierdie boodskap regtig hoor, se sonde word hom vergewe. Of die mens wat die belofte hoor: "Ek is by jou", ervaar dat God in die woord self teenwoordig is.

By Van Aarde (2001:149) is daar tog 'n onduidelikheid in hierdie verband omdat hy in verwysende taal na die verkondiging verwys as "the stories about Jesus", terwyl hy die performatiewe aard van die boodskap bedoel en Luther daarby aanhaal "das in der Bibel sprechende Wort" (Van Aarde 2001:159). Aan die een kant word die woord van sy krag ontneem om 'n blote "retelling" te word, maar aan die ander kant word daar weer soveel van die woord verwag. Miskien kan die noem van hierdie teenstrydigheid vir Van Aarde die aanleiding gee tot meer uitvoerigheid.

Hoewel dit vir die nuweling in die geloof nog nie so duidelik is nie, is die heilswerklikheid verder vir die Nuwe-Testamentiese skrywers 'n eenheid wat nie in verskillende feite opgedeel kan word nie. In die verkondiging word die sogenaamde feite van geboorte, kruis en verhoging aangebied as God se heilsdaad aan die wêreld. Die aangesprokenes hoor hierin dat hulle geken word as sondaars wat genade ontvang. Die gelowige hou by een saak, naamlik dat hy met God versoen is. Die aanspraak wat God maak, het nie maar net 'n beperkte waarde en beperkte toepassing, dat dit of dat van die mens gevra word nie. As dit so sou wees, sou die aanspraak maar met min erns gemaak kon word. Maar soos dit nou is, lê God sy hand op hele lewens. Verder is die mens ook nie die een wat die inisiatief het soos by objektiewe kennis nie, hy word bevraagteken en hy mag op die aanspraak wat op hom gemaak word, sy antwoord gee.

Die werklikheid van die maagdelike geboorte is kerugmatiese werklikheid en nie natuurlike, biologiese werklikheid nie. Die berig van die maagdelike geboorte is nie reeds waar as dit sou ooreenstem met wat eenmaal biologies gebeur het nie, maar net dan wanneer dit wat daardeur verkondig word, vandag sou gebeur. Die ware hermeneut wil deurdring tot verstaan wat mense kan laat verander (vgl Hübner 2000:16). Die verkondiging 
van die maagdelike geboorte wil nie van Jesus se natuur praat nie, maar wil uitspreek dat God ons in Jesus ontmoet. Die saak wat deur die maagdelike geboorte uitgedruk word, is groter as die uitdrukking daarvan. Die NuweTestamentiese maagdelike geboortetradisie is afhanklik van die evangelie, terwyl die evangelie op sy beurt nie afhanklik van daardie tradisie is nie. Die maagdelike geboortetradisie is wel 'n poging, maar ook net 'n poging om die saak van die evangelie onder woorde te bring. Die saak waarom dit gaan, kan die een preek in al die preke genoem word, die een boodskap, dat God nie sonder mense gedink kan word nie en net die mens wat in die luister hierna ophou om aan homself as sonder God, dit wil sê as dood, te dink, kan dit hoor. Die Bybel is vanselfsprekend ook vry om van hierdie betekenis van Jesus Christus ook in ander vorme as sy geboorte te praat, byvoorbeeld dat Jesus by sy opstanding as "Seun van God" ingestel word (Rom 1:4), of by sy doop as Seun deur God aangeneem word (Mark 1:10-11). Die verskillende voorstellings versteur nie die konsensus wat reeds oor die evangelie bestaan nie. Dit bly die een evangelie, dat God ons in Jesus Christus tegemoet kom, wat deur verskillende voorstellings, teologieë verkondig word. Die geboorte, doop en opstanding van Jesus konstitueer, elkeen op sy beurt volledig, een en dieselfde realiteit. Die werklikheid moet nie in die voorstellings gesoek word nie, maar in die konstante saak wat daardeur aangedui word. Hierdie onderskeid tussen evangelie en teologie, heilshandeling en voorstelling daarvan, boodskap en preek ken en gebruik die fundamentaliste nie (vgl Schmithals 1967:500). Hulle omvorm teologie, voorstelling, preek tot evangelie. So skryf Dr D J C van Wyk (jr) (2002:2) in die redakteurskolom van Die Hervormer van die maagdelike verwekking van Jesus, sy kruisdood en opstanding, die lewe na die dood: "Hierdie sake is immers die kern van die Christelike belydenis soos die kerk van die eeue dit bely het". Ook Van der Westhuizen (2000:19 en 26) kom tot die gevolgtrekking dat "historiese heilsfeite nie maar net metafore (is) nie" en verwys na "sogenaamde verskillende teologieë". Die wesenlike gevaar van hierdie omvorming is dat 'n bepaalde voorstelling as die eintlike saak voorgehou word, dat die modernistiese teologie van die heilsfeite as die eintlike evangelie aangebied word. Wat die maagdelike geboortetradisie betref, as dit evangelie self is, dit wil sê meer as 'n manier van die oordrag van die evangelie, sou ou staatmakers soos Paulus, Markus en Johannes as onbetroubare getuies uitgewys moet word, want hulle het nog nie of nie meer van hierdie vorm van prediking gebruik gemaak nie. 


\section{GODDELIKE WERKLIKHEID EN DIE MENSLIKE VERWERKING DAARVAN}

Om die argument nog verder te voer: Volgens die bewoording van die tweede artikel van die Apostoliese Geloofsbelydenis glo ons in Jesus Christus. Hy is vir ons goddelike werklikheid. Maar hierdie werklikheid wil en moet uitgewerk en verklaar word. Die gemeentelike uitdrukking daarvan vind ons onder andere in die uitdrukking "wat ontvang is van die Heilige Gees, gebore is uit die maagd Maria". Wat nou maklik kan gebeur, is dat die fokus van die geloof verskuif word, weg van die goddelike werklikheid wat verklaar word na die verklaring wat daarvan gegee word. Dit lyk ook veiliger en minder gewaagd om voor die uitleg te buig, want die illusie word geskep dat die erkenning van die goddelike werklikheid die gevolg is van 'n logiese opbou: Omdat Hy van die Heilige Gees ontvang en uit die maagd Maria gebore is, glo ons in Jesus Christus. Die gevolg is egter 'n ontoelaatbare omkering wat die refleksie van die geloof plaas in die posisie van die oorspronklike goddelike werklikheid.

Anders gesê: Volgens hierdie benadering word nog nie die geloof self bely nie, maar vir eers die verkondiging of verklaring van die geloof in Jesus Christus: Hy is ontvang van die Heilige Gees, gebore uit die maagd Maria. Wanneer die verkondiging van die geloof bely word, kan dit nie anders as dat so 'n belydenis as 'n prestasie en verdienste beskou sal word nie, want die inhoud en voorwerp van hierdie belydenis is mensewerk, menslike verwerking van die ontmoeting tussen God en mens, verklaring van die selfopenbaring van God waarvan mense die werklikheid ervaar in die vergewing van sonde. Egte geloof is egter op God self gerig, dit is om deur sy werklikheid oorweldig te word.

Op sy beurt is professor G M M Pelser ook gevangene van die problematiek van die fundamentalisme om nie tussen evangelie en teologie, tussen die goddelike werklikheid en die menslike verwerking daarvan, onderskeid te maak nie. Waar die geykte fundamentalis sê: Een evangelie beteken een teologie, naamlik die fundamentalistiese teologie, erken Pelser die verskeidenheid van teologieë, maar, in 'n nuwe gedaante van fundamentalisme, weet hy nie raad daarmee nie en laat dit hom in die onsekerte oor wat evangelie sou wees.

Hy voel dit ook aan as 'n "permanente krisis" (Pelser, 1988:392) waarin die kerk verkeer deur die spanning wat ontstaan as gevolg van die norm van die verkondiging wat nie eenduidig is nie. Die evangelie verdwyn in die teologieë in. Maar so onseker as wat Pelser dit maak, hoef dit darem nie te wees nie. Die kerk het 'n dogma, dit wil sê die kerk het besluit waaroor dit vir haar gaan: Die erkenning dat Jesus Christus die Here is. Hierdie dogma dring deur tot in die selfbewussyn van die mens en verklaar aan hom hoe dit met 
hom gesteld is, wat die waarheid van sy lewe is. Die mens kan nie anders as om stelling in te neem nie; hy aanvaar of verwerp die boodskap. Die kanon moet gesien word as diensbaar aan die dogma. Die kanon word ingespan om die dogma oor te dra. Die dogma is die konstituerende element van die kanon. Daarom moet die dogma veronderstel word by die ondersoek van die Skrif en behoort dit ook na vore te kom as die resultaat van die Bybelondersoek.

\section{NUWE HERVORMING}

Die beweging wat as die Nuwe Hervorming bekend geword het, meen dat die verwarring so groot is dat ons eintlik van voor af moet begin. Nuwe metafore oor God moet geskep word. Metafoor word hier dan in die sin van evangelie gebruik.

Een van die leidende figure van die Nuwe Hervorming is professor Hansie Wolmarans en in die reëls wat volg, word van sy beskouings bespreek. Wolmarans (2002:211) probeer om 'n verklaring te gee van die oorsprong en wese van die gemeente en die verkondiging, die Christusprediking, soos dit in die tyd van die vroeë kerk neerslag gevind het. Hy verduidelik dat Jesus se volgelinge die betekenis van die historiese Jesus, na sy dood, wou uitlig deur die heroïese patroon van helde uit die Oudheid op Hom van toepassing te maak. "Die historiese Jesus is in terme van bestaande patrone geïnterpreteer" (Wolmarans 2002:211). Jesus het byvoorbeeld soos Dionisius, wat gebore is uit die vereniging van Zeus met die prinses Semele, sy oorsprong uit die swangerskap van 'n prinses uit die geslag van Dawid, Maria, wat deur die Heilige Gees bevrug is (Wolmarans 2002:212). Wolmarans (2002:220) voer aan dat die motief wat die volgelinge van Jesus sou hê om Hom as held voor te stel, sou wees om Hom aanneemlik vir die heidense omgewing te maak. Wolmarans brei egter nie self op die gedagte uit watter reaksie heidene op so 'n boodskap sou hê nie. Sou hulle nie by hulleself kon dink: "O, hier is niks besonders nie, net nog 'n Dionisius" nie? Wolmarans se gedagtes loop meer in die rigting dat Jesus as held die lede van die Christelike gemeenskap sou aanspoor om self heldedade te verrig, byvoorbeeld om begaan te wees oor randfigure soos siekes, armes, nie-Jode en hulle by die gemeenskap in te trek. Mense moet entoesiasties daarvoor gemaak word om te "begin om God en Jesus vir mekaar te wees" (Wolmarans 2002:222). In werklikheid bied Wolmarans 'n psigologiese verklaring aan vir die ontstaan van die Christelike gemeenskap uit die ideaal wat hulle sou hê om helde te wees wat heldhaftige dade verrig, byvoorbeeld deur hulle oor randfigure te ontferm. Jesus is maar net die primus inter pares. In hierdie gedagterigting gaan die teologie as teologie verlore en kan daar hoogstens 


\section{Oor die betekenis van die maagdelike geboortetradisie}

van 'n gesekulariseerde teologie gepraat word, waarin daar nie meer van 'n openbaring van God sprake is of kan wees nie: "Die teologie van God se ingryping word vervang met 'n teologie van menslike verantwoordelikheid" (Wolmarans

2002:223).

Vir baie mense kom dit as 'n skok om te hoor dat bepaalde voorstellings van Jesus Christus uit die Griekse of Joodse omgewing nie oorspronklik op Hom van toepassing was nie, soos byvoorbeeld die heroïese patroon van helde uit die Oudheid. Maar, wat kan mens anders verwag, dit was seker nie vir die vroeë kerk moontlik om ooit uiting aan haar geloof te gee sonder om uitdrukkings uit haar omgewing, tyd en taal daarvoor te gebruik nie. Die enigste maatstaf vir die Christelikheid van so 'n gedagte is of dit "'n bruikbare verwerking aanbied van die oorspronklike ervaring dat God Hom in Christus openbaar.

\section{DIE MAAGDELIKE GEBOORTE}

Hieronder volg 'n uiteensetting van hoe die tradisie van die maagdelike geboorte gebruik kan word om die waarheid van die Christelike boodskap na vore te bring. Die uitdaging van hierdie gedeelte is om die Christelike lewe en leer in die regte verhouding tot mekaar te bring, naamlik dat die leer, byvoorbeeld van die maagdelike geboorte, volg op die lewe in die geloof en daarvan uitdrukking wil wees.

Daar bestaan geen rede waarom die kerk afstand sou doen van die verkondiging van die maagdelike geboorte van Jesus Christus nie, want dit dra betekenis oor, wat ontgin moet word sodat die aanspraak wat daarin vervat is, weer gehoor kan word. Die voor die hand liggende opvatting daaroor is dat dit 'n historiese feit is waarvan objektief kennis geneem sou kon word om die geloof dan daarop te begrond. Hierdie opvatting maak egter te min van die maagdelike geboorte, want, so gesien maak dit van God 'n voorwerp van ons onbetrokke beskouing en ontneem God van die moontlikheid om ons ontmoetend te bevraagteken en lei nie tot geloof nie, aangesien die mens homself in die posisie van 'n instemmende of afkeurende toeskouer en beoordelaar stel van dit wat God doen. Die kerklike uitgangspunt is eerder dat ons oortuig is van die hoëre gesigspunt van die goddelike werklikheid en dat die verkondiging van die maagdelike geboorte 'n poging is om die waarheid wat die gemeente het, uit te druk en vas te hou. Die tradisie van die maagdelike geboorte staan in diens van wat die kerk in Jesus Christus het en van Hom bely. Die verhaal van die maagdelike geboorte verklaar nie volkome die geheim van die Christelike waarheid nie, 
maar wil die betekenis daarvan laat uitkom. En dit kan ook net gebeur waar mense die geheim reeds erken.

Oor die bestaande verhouding met God doen die gemeente verantwoording. Die maagdelike geboorte word verkondig om God se ingryping tot heil van die wêreld aan en deur Jesus Christus te verwoord. Die verkondiging van die maagdelike geboorte is dus die vrug van die geloofslewe van die gemeente. God neem die inisiatief in die gebeure om sy Seun by ons te kry (vgl Luk 1:35), omdat Hy nie sonder mense wil wees nie. Die onheil van die wêreld bestaan daarin dat mense hulleself sonder God wil verwesenlik. Hierdie versteuring in die verhouding tussen God en mens bestaan egter nie net in die gevoel van die mens nie, dit is ook werklikheid. Maar, deurdat God in Jesus Christus ons tegemoet kom en Homself aan die kant van die sondige mens stel, laat Hy vir die mens die moontlikheid om homself as die grond en oorsprong van sy lewe te laat vaar en om in die hoop op God se genade sy ware lewe te vind (vgl Matt 1:21). Deur die verkondiging van die maagdelike geboorte verklaar die Kerk dat ons Jesus as die Here van ons lewe erken. Jesus Christus is die Here, want Hy maak ons vry van die mag van die sonde.

Hoe God opsigself is, weet ons nie, maar in Jesus Christus ontmoet Hy ons. Hy is teen ons as sondaars, maar vir ons as vergeefde sondaars en so hou Hy 'n verhouding met ons in stand. Die werklikheid van die verhouding waarin Hy ons betrek kom eerste, hoe dit verwoord word, byvoorbeeld in die verkondiging van die maagdelike geboorte van Jesus Christus, kom tweede en is afhanklik van die blye geloofsversekerdheid. Op sy beurt help die verkondiging van die maagdelike geboorte weer die gemeente om nie van die verhouding waarin hulle met God staan, te vergeet nie.

Die uitdrukking "maagdelike geboorte" is kerklike taal. Die bedoeling is nie om die historiese Jesus deur besondere menslike eienskappe uit te sonder nie, maar om te sê dat Hy vir die kerk meer as net 'n mens is - Hy het volmag ontvang om God aan ons bekend te stel.

\section{Literatuurverwysings}

Barr, J [1977] 1981. Fundamentalism. London: SCM.

Hübner, H 2000. Nietzsche und das Neue Testament. Tübingen: Mohr.

Pelser, G M M 1988. Die kanon in die kanon as hermeneuties-teologiese probleem.

HTS 44, 388-403.

Schmithals, W 1967. Kerygma und Heilstatsachen: Kein anderes Evangelium, KiZ 11, 493-500.

Van Aarde, A 2001. The "cause of Jesus" (Sache Jesu) as the Canon behind te Canon, HTS 57(1\&2), 148-171.

Van der Westhuizen, H G 2000. Nuwe Ongeloof. Pretoria: Sentik. 
Oor die betekenis van die maagdelike geboortetradisie

Van Wyk, D J C (jr) 2002. Glo ons nog in dieselfde God? Die Hervormer, 15 Junie 2002.

Wolmarans, J L P 2002. Jesus, die heroïese patroon en ons, in Muller, P (red), Die Nuwe Hervorming, 196-224, 241-248. Pretoria: Protea. 